\title{
Bloody Milk in Buffalo Cows: Diagnosis and Trials for Treatment
}

\author{
ELsayed M. Nour ${ }^{1}$; Mohamed F. Taha ${ }^{2}$; Mohamed I. Abdou ${ }^{*}$, Mohamed E. Abdelfattah ${ }^{3}$ and
} Elsayed G. Mohamed ${ }^{3}$

${ }^{1}$ Biochemistry Department, Animal Health Research Institute, Zagazig Provincial Lab

${ }^{2}$ Bacteriology Department, Animal Health Research Institute, Zagazig Provincial Lab

${ }^{3}$ Food hygiene Department, Animal Health Research Institute, Zagazig Provincial Lab

Article History: Received: 25/8/2016 Received in revised form: 24/11/2016 Accepted: 10/12/2016

\begin{abstract}
The present study was conducted on 80 composite milk samples collected from dairy buffaloes secreting bloody milk from all four quarters without any inflammatory signs on mammary gland, systemic reaction or decrease in milk yield at Sharkia Governorate. Somatic cell count (SCC) revealed that 46 samples $(57.5 \%$ ) have SCC range between 200,000 to 250,000 cell $/ \mathrm{mL}$, while, 34 samples $(42.5 \%)$ have SCC below 200,000 cell $/ \mathrm{mL}$. California mastitis test (CMT) was negative for 65 out of $80(81.3 \%)$ and positive in 15 out of $80(18.7 \%)$. Bacteriological examination revealed that 56 out of 80 samples $(70 \%)$ were bacteriologically positive and 24 $(30 \%)$ were bacteriologically negative. Coagulase positive Staphylococcus aureus were identified in 14 out of $56(25 \%)$, however, 42 samples out of $56(75 \%)$ were contaminated with coagulase negative Staphylococci (CNS), 20 of them had SCC less than 200,000 X $10^{3}$. All Coagulase positive $S$. aureus were isolated from milk of SCC between $200 \times 10^{3}$ to $250 \times 10^{3}$ cell $/ \mathrm{mL}$. Antibiotic sensitivity test revealed that Gentamycin, Amoxycillin + Clavuylinic acid and Enrofloxacin were the most effective antibiotics on both S. aureus and CNS. Group 1, 2 and 3 (bacteriologically positive cases) were treated with Gentamycin, Amoxicillin + Clavulenic or Enrofloxacin in addition to coagulant (Amri-K) showed cure rate of $80 \%, 80 \%$ and $60 \%$, respectively. Group 4 that contained animals with negative bacteriological culture were treated by coagulant (Amri-K) only, showed cure rate of $60 \%$. However, the return rate of the disease was $0,20,40$ and $40 \%$, respectively. Biochemical and hematological parameters showed nonsignificant differences between bloody milk and healthy control dairy buffaloes. This study concluded that either coagulase positive or coagulase negative $S$. aureus is incriminated with the bloody milk syndrome in dairy buffaloes in Egypt, however, Gentamycin in addition to coagulant (Amri-k) is the best treatment.
\end{abstract}

Keywords: Bloody Milk, Buffalo Cows, SCC, S. aureus, Amri-K.

\section{Introduction}

Blood tinge or haematogalactia in milk could be attributed to injury in capillaries of mammary glands. Sometimes this situation becomes worse when brown chocolate colour (Haematogalactia) secretions are voided from lactating female buffaloes instead of milk [1]. Somatic cell count (SCC) of milk is the actual index of quarter intra-mammary infection, two types of cells, namely, sloughed epithelial cells from the udder cell population and leukocytes from the blood can be detected [2]. The epithelial cells are present in the normal milk as a result of normal breakdown and repair process, while, leukocytes enter in milk from blood, being attracted by chemical substances released from injured mammary tissue. Most of somatic cells are leukocytes, which include macrophages, lymphocytes and neutrophils. Epithelial cells range from $0-7 \%$ of SCC but the main increase in SCC occurs due to the influx of neutrophils into the milk. The level of somatic cell increases with the severity of mastitis [2].

Presence of somatic cells (Leukocytes) in milk indicates the disease combating response in animals and is the actual index of level of 
inflammation in mammary gland quarters. In composite milk samples (from all four quarters), SCC of less than 200,000 cells/mL is used as an indication of infection [3]. A positive diagnosis of mastitis should fulfill two criteria, a positive bacteriological test and an inflammatory cellular change [4]. Milk from uninfected quarters displays little change in SCC as number of lactations increases. Somatic cell count of milk from uninfected quarters rose from 83,000 cell $/ \mathrm{mL}$ at 35 days postpartum to 160,000 cell $/ \mathrm{mL}$ by day 285 . Somatic cell counts in milk samples from individual animals can be performed using California Mastitis Test (CMT), in which the reagent reacts with genetic material of somatic cells present in milk to form a gel. For reliable results, tests should be conducted just before milking after stimulating milk letdown and discarding the foremilk [5].

The most frequently isolated bacteria from milk samples of mastitis in previous studies were coagulase negative Staphylococcus (CNS) followed by Corynebacterium spp. and Streptococcus spp. [6]. The aim of the present work is to investigate the bloody milk problem in dairy buffaloes in Egypt. Bacteriological and biochemical examination was conducted to identify the causal agents with some trials of treatment after antibiotic sensitivity testing.

\section{Material and Methods}

\section{Animals}

The present study was carried out on 80 buffaloes, reared individually from private Buffalo farms at Sharkia Governorate during the period between December 2013 and April 2015. There was no elevation in the body temperature and animal appeared with healthy udder. The secretions of the udder were normal milky color but the owners' complaints were a reddish layer float above the surface of the milk after overnight period or slightly bloody milk at milking without any signs of inflammation or decrease milk production. Cases of physiological bloody milk that occur once after parturition were excluded.

\section{Samples}

A total of 80 composite milk samples (pool of the four quarts) of $50 \mathrm{~mL}$ were collected aseptically from each animal and placed in sterile screw capped bottles [7]. After dry cleaning of the udder, discharging of the first milk squirts, drying of teats thoroughly with an individual towel, apex disinfection with gauze and alcohol $70 \%$ were carried out. California mastitis test (CMT) was performed in the field as previously described by Schalm et al. [8]. The samples were transported in an ice box as soon as possible to the laboratory for further examination. Portion of the milk samples was used for Somatic cell count (SCC) and the other portion for bacteriological examination.

\section{Somatic Cells Count (SCC)}

Somatic cells count (SCC) was determined as soon as possible at Animal Health Research Institute, Zagazig Lab using somatic cell counter (MT05, manufactured by PISOFT, SLOVAK REPUBLIC).

\section{Preparation and bacteriological examination of milk samples}

Ten milliliters of each milk sample were centrifuged at $3000 \mathrm{rpm}$ for $15 \mathrm{~min}$, and the sediment was subjected to bacteriological examination. Intact erythrocytes were detected microscopically. One hundred microliters of milk samples were streaked directly on to MacConkey and 5\% sheep blood agar plates [9]. The plates were incubated aerobically at $37^{\circ} \mathrm{C}$ for 24 to $48 \mathrm{~h}$. Subcultures of the resulting growth was made on Mannitol Salt Agar for purification of the isolates and identification on the basis of Gram's reaction, morphological findings, colony characteristics and biochemical reactions. Staphylococcus species were identified on the basis of catalase, type of haemolysis on blood agar and rabbit plasma coagulase [10].

\section{Antibiotic sensitivity test}

The isolated coagulase positive Staphylococcus aureus and coagulase negative Staphylococci were subjected to antimicrobial susceptibility test by disc diffusion method [10]. Sensitivity was measured against 10 antimicrobials including Enrofloxacin $(5 \mathrm{mg})$, 
Gentamycin (10 mg), Ciprofloxacin (5 mg), Sulfamethoxazole+Trimethoprim (25 mg), Tetracycline (30 mg), Amoxycillin+Clavulenic acid $(30 \mathrm{mg})$, Vancomycin $(30 \mathrm{mg})$, Oxytetracycline $(1 \mathrm{mg})$, Flourofenicol $(30 \mathrm{mg})$ and Cefotriaxone (30 mg).

\section{Hematological and biochemical examination}

Two blood samples were collected from the jugular vein of five apparently healthy control and five randomly chosen bloody milk buffaloes. The first sample was collected with heparin for hematological examination [11]. The second blood sample was collected without anticoagulant for serum separation for biochemical analysis. Serum total protein and albumin were measured by spectrophotometer $[12,13]$, also, serum calcium and inorganic phosphorous were estimated $[14,15]$. Serum Haptoglobin level was determined by Turbidimeteric methods that described according to the manufacturer's guidelines (Beckman Coulter, Inc., USA), while Creactive protein was also determined (Biosystems S.A. (Spain) \& Bio- Med Diagnostics, Egypt).

\section{Treatment regime}

Four groups were randomly chosen from bloody milk buffaloes under study to be treated by different sensitive antimicrobials. Animals in Group $1 \quad(n=5)$ were treated by Gentamycin 10\% (I.M injection of $4 \mathrm{~mL} / 100$ $\mathrm{kg} \mathrm{BW}$, daily, divided into two doses for 3 successive days. Group 2, consisted of five animals, were treated by Amoxicillin+ clavulenic acid (Synulox, Pfizer animal health) by I.M injection of $1 \mathrm{~mL} / 20 \mathrm{~kg} \mathrm{BW}$, two doses with 3 days interval. Animals in Group $3(n=5)$ were treated by enrofloxacin 10\% (Enroflox, El-Nasr, Egypt) by I.M injection of $1 \mathrm{~mL} / 20$ $\mathrm{kg}$ BW for 3 successive days. Group 4 consisted of five animals that were negative for bacteriological examination, they were treated by Vit. $\mathrm{K}$ precursor (Amri-K) as coagulant in a high dose (12 ampules) for five successive days. The first three groups were injected also by coagulant (Amri-k) for five successive days. The cured buffaloes (which did not produce blood in milk after treatment) and recurrent cases (animals produced blood in milk after treatment and curing) were recorded to estimate the cure and return rates.

\section{Statistical analysis}

The obtained results for hematological and biochemical parameters are represented as mean \pm standard error (S.E.) and results with $P$ $\leq 0.05$ were considered significantly different [16]. The results were statistically analyzed using Student's t-test. SPSS version 21, IBM Corp., Chicago, IL, USA was used for all analyses.

\section{Results and Discussion}

Buffaloes are mostly reared for milk production in Egypt. The decrease in milk production and the presence of blood alone in milk or milk mixed with mucus are of the most important reasons for termination of lactation and unwanted culling of dairy buffaloes [17]

The present study revealed that, centrifugation of the milk samples resulted in sedimentation of erythrocytes in the form of a bead at the bottom of the conical centrifugation tube. Also, microscopical examination of wet milk film from the sediment revealed the presence of intact erythrocytes which exclude the red color of the milk that appears homogenous in the test tube either in case of milk pigment of red color or in case of leptospirosis. However, the milk in leptospirosis, is not expected to contain intact erythrocyte but may be stained red due to the hemoglobin as the disease involves the elaboration of a haemolysin by leptospirae [18]. 
Table 1: Bacteriological examination of bloody milk samples collected from buffaloes in relation to that of somatic cell counts $(\mathrm{SCC})(\mathrm{N}=\mathbf{8 0})$

Positive samples for bacteriology

$(\mathrm{N}=56)$

$\mathrm{SCC}<200 \times 10^{3}$

$\mathrm{SCC}=200 \times 10^{3}-250 \times 10^{3}$

Negative samples for bacteriology

$(\mathrm{N}=\mathbf{2 4})$

\begin{tabular}{|c|c|c|c|c|c|c|c|}
\hline \multicolumn{2}{|l|}{$C<2$} & \multicolumn{2}{|l|}{$\mathrm{C}=200 \times 1$} & \multicolumn{2}{|c|}{$0^{3}$} & \multicolumn{2}{|l|}{$\mathrm{CC}=21$} \\
\hline & & & & & & & \\
\hline & & & & & & & \\
\hline \multicolumn{4}{|c|}{$\begin{array}{l}\text { fornia } \\
\text { n } 65 \\
\text { nples. } \\
8.7 \%) \\
\text { sitive } \\
\text { CMT } \\
1 \text { and } \\
\text { or the } \\
\text { matic } \\
\text { ts of } \\
\text { milk } \\
70 \%) \\
\text { SCC } \\
\text { mples } \\
\text { other } \\
\text { urally } \\
000 \text { to }\end{array}$} & \multicolumn{4}{|c|}{$\begin{array}{l}\text { et al. } \\
\text { er than } \\
\text { rences } \\
\text { and } \\
\text { animal } \\
\text { age of } \\
\text { explain } \\
\text { gives } \\
\text { uld be } \\
\text { cannot } \\
\text { ithelial } \\
\text { riation } \\
\text { vith or } \\
\text { afected } \\
\text { have } \\
\text { afected } \\
\text { cows } \\
\text { than }\end{array}$} \\
\hline
\end{tabular}

Table 2: Bacterial species isolated from bloody milk samples of buffaloes in a relation to somatic cell counts (SCC).

\begin{tabular}{|c|c|c|c|c|}
\hline SCC (number) (Cell/mL) & Total No. of samples & Bacterial species & $\begin{array}{c}\text { Positive samples } \\
\text { No. }\end{array}$ & $\%$ \\
\hline $\begin{array}{l}200 \times 10^{3}-250 \times 10^{3} \\
(36)\end{array}$ & & $\begin{array}{c}\text { Coagulase positive } \\
\text { S. aureus }\end{array}$ & 14 & 25 \\
\hline & 56 & $\begin{array}{l}\text { Coagulase negative } \\
\text { Staphylococci }\end{array}$ & 22 & 39.29 \\
\hline $\begin{array}{l}<200 \times 10^{3} \\
(20)\end{array}$ & & $\begin{array}{l}\text { Coagulase negative } \\
\text { Staphylococci }\end{array}$ & 20 & 35.71 \\
\hline
\end{tabular}

The number of somatic cells in milk is generally high in different circumstances such as summer months, the beginning and end of lactation, age, genetic history of the cow and the functional disorder of its reproductive organs [24]. Moreover, a difference of $25 \%$ from one day to another can be expected and cows in one herd may react differently to 
infection than cows from another herd [25]. Therefore, low cell count does not reflect the true bacteriological status of the udder. Also, the significance of latent mastitis which revealed a negative culture with SCC above $200,000 / \mathrm{mL}$ cannot be neglected. Since, some of these cases are likely to convert into the subclinical form and subsequently into clinical mastitis, particularly under unfavorable environmental conditions [26].

Somatic cell counts increased more during summer months from June to August in Holstein cows than in cooler months [21].
Moreover, latent infection also reflects the possibility of teat canal infections serving as a potential source of infection to the milk secretory tissue. Even mammary parenchyma may be damaged due to liberation of bacterial toxins in the infected teat canal.Failure to detect pathogens in such cases might be due to intermittent excretion of the organisms or their disappearance because of spontaneous recovery and this may be ascribed to instantaneous use of antibiotics in the animals by the owners themselves $[27,21]$.

Table 3: Antibiotic sensitivity results of Staphylococcus species isolated from bloody milk samples of buffaloes

\begin{tabular}{|c|c|c|c|c|c|}
\hline \multirow[t]{2}{*}{ Antimicrobial agent } & \multirow[t]{2}{*}{$\begin{array}{c}\text { Code and } \\
\text { potency }\end{array}$} & \multicolumn{2}{|c|}{$\begin{array}{c}\text { Coagulase positive } S \text {. } \\
\text { aureus }(14) \text { sensitive } \\
\text { samples }\end{array}$} & \multicolumn{2}{|c|}{$\begin{array}{c}\text { Coagulase negative } \\
\text { staphylococci }(42) \\
\text { sensitive samples }\end{array}$} \\
\hline & & No. & $\%$ & No. & $\%$ \\
\hline Enrofloxacin & $\mathrm{ENR}_{5}$ & 13 & 92.85 & 37 & 88.09 \\
\hline Gentamycin & $\mathrm{CN}_{10}$ & 14 & 100 & 40 & 95.23 \\
\hline Ciprofloxacin & $\mathrm{CIP}_{5}$ & 13 & 92.85 & 38 & 90.47 \\
\hline Sulfamethoxazole+Trimethoprim & $\mathrm{SXT}_{25}$ & 10 & 71.42 & 32 & 76.19 \\
\hline Tetracycline & $\mathrm{TE}_{30}$ & 7 & 50 & 2 & 4.76 \\
\hline Amoxycillin+Clavulenic acid & $\mathrm{AMC}_{30}$ & 14 & 100 & 38 & 90.47 \\
\hline Vancomycin & $\mathrm{VA}_{30}$ & 13 & 92.85 & 36 & 85.71 \\
\hline Oxytetracycline & $\mathrm{OX}_{1}$ & 2 & 14.29 & 5 & 11.9 \\
\hline Flourofenicol & $\mathrm{FFC}_{30}$ & 2 & 14.29 & 2 & 4.76 \\
\hline Cefotriaxone & $\mathrm{CRO}_{30}$ & 3 & 21.42 & 20 & 47.61 \\
\hline
\end{tabular}

The bacteriological examination of milk samples revealed that Staphylococcus spp. was the only organism isolated from bloody milk samples of buffaloes in the present study (Table 2). From these isolates, 14 out of 56 (25\%) were coagulase positive S. aureus and all of them were isolated from samples with SCC ranged from 200,000 to 250,000 cell $/ \mathrm{mL}$. The remaining 42 out of 56 isolates (75\%) were coagulase negative Staphylococci (CNS). These results were nearly similar to other reported investigations [28-31]. Out of 38 bacteriologically positive buffalo milk samples in India, a total of 44 isolates were identified, of which, $15.9 \%$ were coagulase positive $S$. aureus and $47.7 \%$ were CNS [21]. In Iran, $38.9 \%$ of the examined milk samples were contaminated with CNS [32]. However, in India, $13.7 \% \mathrm{CNS}$ were isolated from milk of subclinical mastitic cows [33]. The higher susceptibility of milking buffaloes to pathogens could be due to several reasons such as; unhygienic milking places, close contact between healthy and diseased animals in common grazing and wallowing places, unhygienic milking procedures, exposure of teats to injury with inverted thumbs and unweaned calves, pulling and hitting the udder resulting in injury and infection [34]. 
Table 4: Erythrogram and Leukogram (Mean values \pm S.E) of healthy and bloody milk buffaloes $(\mathrm{N}=5)$

\begin{tabular}{|c|c|c|}
\hline Parameters & $\begin{array}{c}\text { Healthy control buffaloes } \\
\text { Group (I) }\end{array}$ & $\begin{array}{c}\text { Bloody milk buffaloes } \\
\text { Group (II) }\end{array}$ \\
\hline $\operatorname{RBCS}(\mathrm{X10} / \mu \mathrm{L})$ & $6.90 \pm 0.15$ & $6.56 \pm 0.06$ \\
\hline Hb (g/dl) & $11.24 \pm 0.43$ & $10.46 \pm 0.24$ \\
\hline $\operatorname{PCV}(\%)$ & $31.70 \pm 0.60$ & $30.30 \pm 0.46$ \\
\hline $\operatorname{MCV}(\mathrm{FL})$ & $46.01 \pm 0.97$ & $46.20 \pm 0.51$ \\
\hline $\operatorname{MCH}(\mathbf{P g})$ & $16.28 \pm 0.36$ & $15.95 \pm 0.33$ \\
\hline MCHC (g/dl) & $35.42 \pm 0.91$ & $34.51 \pm 0.49$ \\
\hline Platelets $(\operatorname{count} / \boldsymbol{\mu L})$ & $354 \pm 31.24$ & $293 \pm 17.64$ \\
\hline $\operatorname{TLC}\left(X 10^{3} / \mu L\right)$ & $7.87 \pm 0.38$ & $8.13 \pm 0.43$ \\
\hline Neutrophil (\%) & $39.75 \pm 0.85$ & $41.25 \pm 1.11$ \\
\hline Lymphocyte (\%) & $55 \pm 0.71$ & $53.25 \pm 1.18$ \\
\hline Eosinophil (\%) & $1.75 \pm 0.25$ & $1.25 \pm 0.25$ \\
\hline Monocyte (\%) & $3.5 \pm 0.50$ & $4.25 \pm 0.25$ \\
\hline Basophile (\%) & 0.00 & 0.00 \\
\hline
\end{tabular}

*group(II )was contained 4 groups and group (I) was a healthy control. *values did not show any significant differences at $p<0.05$

Regarding the antibiotic sensitivity test of the obtained isolates the results in Table (3) revealed that, Gentamycin and Amoxycillin+Clavulenic acid were the most effective antibiotics on coagulase positive $S$. aureus (100\%, each) followed by Enrofloxacin, Ciprofloxacin and Vancomycin (92.85\% for each), however, Gentamycin was the best effective antibiotic (95.23\%) on coagulase negative Stapylococci followed by Amoxycillin+Clavulenic acid and Ciprofloxacin (90.5\%), Enrofloxacin (88.1\%) and Vancomycin (85.7\%). On the other hand, Tetracycline, Oxytetracycline, Flourofenicol and Cefotriaxone were the lowest effective antibiotics on both coagulase positive $S$. aureus and CNS. The current study agrees with Rossetti [35] who found that $100 \%$ of $S$. aureus, the most commonly isolated pathogen from mastitis, were sensitive to Gentamycin. Similarly, Gentamycin and Enrofloxacin were reported to be the most effective drugs against S. aureus [36]. Recently a higher susceptibility of S.aureus and Escherichia coli to Amoxycillin+Clavulenic acid and Enrofloxacin was also reported [30]. S. aureus showed a higher susceptibility to Cotrimoxazole (100\%) and Oxytetracycline [27].
The efficacy of treating buffaloes with bloody milk revealed that, Groups 1, 2 and 3 (bacteriologically positive cases) were treated with Gentamycin, Amoxicillin+Clavulenic or Enrofloxacin in addition to coagulant (Amri$\mathrm{K})$ and showed cure rates of $80 \%, 80 \%$ and $60 \%$, respectively. Group 4 that contained animals with negative bacteriological culture were treated by coagulant (Amri-K) showed recovery of $60 \%$ of the animals. However, the recurrence of bloody milk in the treated animals was with the percentages of zero, 20, 40 and $40 \%$ in the four groups, respectively. Treatment of buffaloes suffering from bloody milk syndrome with Gentamycin $10 \%$ in addition to coagulant induced the best results. The cure rate in this study ranged between 60$80 \%$ which is higher than that recorded in ten Dutch herds (34\%) treated from subclinical $S$. aureus mastitis [37]. All treated cases in our study were in the lactation period and the successful treatment during lactation is greater if detected and treated early, whereas, the response is lower when treating chronic infections [38]. The intermittent changing pattern of antibiotic susceptibility against Stapylococci could be attributed to the misuse of different antibiotics resulting in development of resistance [27]. 
Table 5: Some biochemical parameters (Mean values \pm S.E) of healthy and bloody milk buffaloes $(\mathrm{N}=5)$

\begin{tabular}{lcc}
\hline Parameters & $\begin{array}{c}\text { Healthy control buffaloes } \\
\text { Group (I) }\end{array}$ & $\begin{array}{c}\text { Bloody milk buffaloes } \\
\text { Group (II) }\end{array}$ \\
Total protein (g/dl) & $7.68 \pm 0.09$ & $7.97 \pm 0.12$ \\
Albumin (g/dl) & $3.86 \pm 0.17$ & $3.69 \pm 0.20$ \\
Globulins (g/dl) & $3.82 \pm 0.15$ & $4.28 \pm 0.29$ \\
Calcium (mg/dl) & $10.26 \pm 0.13$ & $10.82 \pm 0.21$ \\
Phosphorous (mg/L) & $6.93 \pm 0.23$ & $6.44 \pm 0.30$ \\
C-reactive protein (mg/L) & $5 \pm 0.71$ & $6.75 \pm 0.63$ \\
Haptoglobin (g/L) & $0.49 \pm 0.04$ & $0.66 \pm 0.06$ \\
\hline
\end{tabular}

* group(II) was contained 4 groups and group (I) was a healthy control. *values did not show any significant differences at $p<0.05$.

The results in Table (4) revealed a non significant reduction in $\mathrm{RBCs}, \mathrm{Hb}, \mathrm{PCV}$ and platelets values in buffaloes secreted blood tinged milk. The values of TLC, Neutrophil, serum total protein, globulins and inflammatory markers (C-reactive protein and Haptoglobin) showed a non significant elevation in the affected buffaloes (Tables 4 and 5). These findings indicated the localization of the infection in the udder that produced minimal systemic reaction. Serum Calcium and Phosphorous were within normal levels.

Complete blood count (CBC) including the leukon and erythron evaluation is commonly used to assess the systemic status of sick animals [39]. However, it has been reported that changes in the hematological and biochemical analyses in cases of mastitis were limited to those caused by Gram-negative bacteria but not Gram-positive bacteria [3942]. Lack of endotoxemia in cases of clinical mastitis caused by Gram-positive bacteria was suggested as an explanation for this difference [40]. Our results were in contrary to Faris and Selim [43] who noticed significant decrease in the values of RBCs, $\mathrm{Hb}, \mathrm{PCV}$ and Platelets in addition to serum calcium, while TLC, neutrophil, serum total protein, and globulin were significantly increased in buffaloes secreting bloody milk.

\section{Conclusion}

It could be concluded that, biochemical and bacteriological examination of bloody milk cases must be conducted before beginning of treatment. Gentamycin $10 \%$ in addition to coagulant induced the best results.
The annual occurrence of bloody milk cases in the period extended from December to April denotes the need for further epidemiological investigations.

\section{Conflict of interest}

The authors declare no conflict of interest.

\section{References}

[1] Ayaz, M.M. (1999): Haematogalactia in goats and buffalo. Pakistan Vet j, 19(3):161- 162.

[2] Miller, R.H. and Paape, M.J. (1985): Effects of parity, bacteriological status, stage of lactation, and dry period on $\mathrm{N}$ acetyl-B-D-glucosaminidase activity of milk and dry secretions. J Dairy Sci, 71(9): 2508-2512.

[3] Sharif, A.; Ahmad, T.; Bilal, M.Q.; Yousaf, A.; Muhammad, G.; Rehman, S.U. and Pansota, F.M. (2007): Estimation of milk lactose and somatic cells for the diagnosis of sub-clinical mastitis in dairy buffaloes. Int J Agric Biol, 9: 267-270.

[4] Katsoulos, P. D.; Christodoulopoulos, G.; Minas, A.; Karatzia, M. A. Pourliotis, K.; and Kritas, S. K. (2010): The role of lactate dehydrogenase, alkaline phosphatase and aspartate amino transferase in the diagnosis of subclinical intramammary infections in dairy sheep and goats. J Dairy Res,77(1):107-111.

[5] Khan, M.Z. and Khan, A. (2006): Basic facts of mastitis in dairy animals: A review. Pakistan Vet J, 26 (4): 204-208. 
[6] Naiknaware, H.S.; Shelke, D.D.; Bhalerao, P.P.; Keskar, D.V.; Jagadesh, S. and Sharma, L.K. (1998): Prevalence of subclinical mastitis in buffaloes in and around Mumbai. Indian Vet J, 75(4): 291-292.

[7] National Mastitis Council publication (2004): Procedures for collecting milk samples. In: microbiological procedures for the diagnosis of bovine udder infection and determination of milk quality: 24.

[8] Schalm, O. W.; Carroll, E. J. and Jain, N. C. (1971): Number and types of somatic cells in normal and mastitic milk. In: Schalm, O. W., Caroll, E. J. and Jain, N. C. (eds), Bovine mastitis, $1^{\text {st }}$ ed, pp. 94-127. Lea and Febiger, Philadelphia.

[9] Hogan, S.J.; Gonzalez, R.N.; Harmon, J.R.; Nickerson, S.C.; Oliver, S.P.; Pankey, J.W. and Smith, L.K. (1999): Laboratory handbook on Bovine mastitis, (National Mastitis Council, Inc., WD Hoard, Fort Atkinson, USA).

[10] Quinn, P.J.; Carter, M.E.; Markey, B.K. and carter, G.R. (1994): Clinical Vet. Microbiology, $1^{\text {st }}$ edition, published by Wolf publishing on imprint of mostyear Book limited. Europe Limited.

[11] Jain, W. (1986): Schalms Veterinary Hematology. $4^{\text {th }}$ Ed., Lee and Fibiger, Philadelphia U.S.A.

[12] Peters, T. (1968): Colorimetric method for determination of total protein. Clin Chem, 17: 1147.

[13] Webster, B. (1974): Colorimetric determination of serum albumin. Clin Chem Acta, 53: 109-116.

[14] Tietz, N.W. and Berger, S. (1970): Fundamentals of clinical chemistry. Philadelphia: Saunders. $6^{\text {th }}$ edition, $602-$ 609.

[15] El-Merzabani, M.M.; El-Aaser, A.A. and Zakhry, N.I (1977): A new method for determination of inorganic phosphorus in Serum without deproteinization. $\mathbf{J}$ Clin Chem Clin Biochem, 15: 715-718.
[16] Snedecor, G.W. and Cochran, W.G. (1994): Statistical Methods ( $8^{\text {th }}$ Ed.). Iowa State Univ. press.USA.

[17] McDowell, R.E.; Wilk, J.C.; Shah, S.K.; Balain, D.S. and Metry, G.H. (1995). Potential for commercial dairyingwith buffaloes. North Carolina State University, USA.

[18] Muhammad, G.; Zia T.; Athar, M. and Khan M. Z. (1997): Haematogalactia (Blood in milk) in a buffalo. Pakistan Vet J, 17 (2): 102-103.

[19] Babaei, H.; Mansouri, N.; Molaei, M. M.; Kheradmand, A. and Sharifan, M. (2007): Assessment of lactate dehydrogenase, alkaline phosphatase and aspartate aminotransferase activities in cow's milk as an indicator of subclinical mastitis. Vet Res Commun, 31(4): 419425.

[20] Chavan, V.V.; Digraskar, S.U.; Dhonde, S.N. and Hase. P.B. (2007): Observation on bubaline subclinical mastitis in and around Parbhani. Indian $\mathbf{J}$ Field Vet, 3: 50.

[21] Pankaja, M.; Sharma, A.; Chhabra, R. and Sindhu, N. (2013): Subclinical mastitis in Murrah buffaloes with reference to prevalence, etiology and antibiogram. Buffalo Bulletin, (2)32:107-115.

[22] Sharma, D.K.; Jallewar, P.K. and Sharma, K.K. (2007): Antibiogram of bacteria isolated from bovine subclinical mastitis. Indian Vet J, 87(4):407.

[23] Jones, G.M.; Pearson, R.E.; Clabaugh, G.A. and Heald, C.W. (1984): Relationships between somatic cell counts and milk production. J Dairy Sci, 67(8): 1823-31.

[24] Hanus, O. and Suchanek, B. (1991): Variability and somatic cell counts in cow's milk as influenced by some internal and external factors. Zivocisna Vyroba -UVTIZ (CSFR), 36(4): 30033011.

[25] Natzke, R.P. (1978): Detection of mastitis. In Wilcox, D.J. et al., (1978): Dairy herd management. Pp 537 -546. 
University of Florida, Gainesvilly, Florida.

[26] Roder, R. and Gedek, W. (1986): Milk cell counts associated with different mastitis pathogens. Berl Munch Tierarztl, 99(3):73-76.

[27] Hussain, A.; Shakoor, A.; Yousaf, A.; Rehman, S. U. and Zaman, M. A. (2012): Clinical and subclinical Staph. auerus in dairy buffaloes: Disease characteristic and antibiotic susceptibility profiles of isolates. J Anim Plant Sci, 22(Suppl 3):217-220.

[28] Ali, M. A.; Ahmad, M. D.; Muhammad, K. and Anjum, A. A. (2011): Prevalence of subclinical mastitis in dairy buffaloes of Punjab and Pakistan. J Anim Plant Sci, 21(3):477-480.

[29] Guha, A.; Guha, R. and Gera, S. (2012): Comparison of somatic cell count, California mastitis test, chloride test and rennet coagulation time with bacterial culture examination to detect subclinical mastitis in river buffalo (Bubalus bubalis). Afr J Agric Res, (7)41:55785584 .

[30] Abd-Elrahman, A.M. (2013) :Mastitis in housed dairy buffaloes: incidence, etiology, clinical finding, antimicrobial sensitivity and different medical treatment against E. coli mastitis. Life Sci J, 10 (1): 532-538.

[31] Mohamed, A.A.; Wahba, A.K.A.; Faisal, R.A.S.R. and Yousreya, H.M. (2013): Some Bacteriological and Biochemical Studies on Subclinical Mastitis in Buffaloes. New York Sci J, (7) 6:71-79.

[32] Ebrahimi, A.; Kheirabadi, K.H.P. and Nikookhah, F. (2007): Antimicrobial susceptibility of environmental bovine mastitis pathogens in west central Iran. Pakistan J Biol Sci, 10 (17):3014-3016.

[33] Botrel, M. A.; Haenni, M.; Morignat, E.; Sulpice, P.; Madec J. Y. and Chavan, D.V., Digraskar, S.U. Dhonde, S.N. and Hase. P.B. (2007): Observation on bubaline subclinical mastitis in and around Parbhani. Indian J Field Vet, 3: 50.
[34] Dhakal, I.P. (2006): Normal somatic cell count and subclinical mastitis in Murrah buffaloes. J Vet Med series B:53(2): 8186.

[35] Rossetti, C.A. (1993): Prevalence of subclinical mastitis caused by Staphylococcus aureus in Buenosaires dairy area and its susceptibility to antibiotics. Vet Argent, 10: 323-326.

[36] Iqbal, M.; Khan, M.A.; Daraz, B. and Saddique, U. (2004): Bacteriology of mastitic milk and in vitro antibiogram of isolates. Pakistan Vet J, 24: 161-164.

[37] Sol, J.; Sampimon, O.C.; Snoep, J.J. and Schukken, Y.H. (1997): Factors associated with bacteriological cure during lactation after therapy for subclinical mastitis caused by Staphylococcus aureus. J Dairy Sci, 80(11): 2803-2808.

[38] Pyorala, S. and Pyorala, E. (1997): Accuracy of methods using somatic cell count and N-acetyl-beta-Dglucosaminidase activity in milk to assess the bacteriological cure of bovine clinical mastitis. J Dairy Sci, 80(11): 2820-25.

[39] Radostits O. M.; Gay C. C.; Hinchcliff K. W. and Constable P. D., (2007) Veterinary Medicine, a textbook of the diseases of cattle, horses, sheep, pigs, and goats. Saunders, Philadelphia, PA, USA.

[40] Smith G. W.; Constable P. D. and Morin D. E. (2001) Ability of hematologic and serum biochemical variables to differentiate Gram-negative and Grampositive mastitis in dairy cows. J Vet Int Med, 15(4): 394-400.

[41] Ismail, B. Z. and Dickinson, C. (2010): Alterations in coagulation parameters in dairy cows affected with acute mastitis caused by $E$. coli and $S$. aureus pathogens. Vet Res Commun, 34(6):533539.

[42] Ismail, B.Z. and Alekish, M. O. (2015): Hematology and serum biochemistry analyses in Awassi sheep affected with clinical and subclinical mastitis caused by Staphylococcus aureus and 
antimicrobial sensitivity patterns of the isolated bacterial strains. $\mathrm{ABAH}$ Bioflux, 7 (2): 202-207.
[43] Faris, A. E. S. and Selim, M.A. (2007): Some biochemical, haematological, and bacteriological studies associating bloody milk in buffalo cows and trials for treatment. Zag Vet J, 35 (3): 95- 103.

$$
\begin{aligned}
& \text { الملخص العزبى الموسن } \\
& \text { اللبن المدمم في الجاموس: التشخيص ومحاولات العلاج }
\end{aligned}
$$

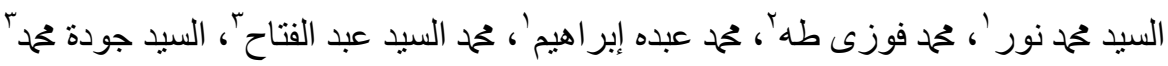

$$
\begin{aligned}
& \text { 'قسم الكيمياء الحيوى- معهد بحوث صحة الحيو ان - معمل الزقازيق الفرعى جـى }
\end{aligned}
$$

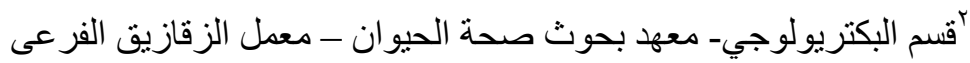

$$
\begin{aligned}
& \text { "قسم صحة الأغذية_معهد بحوث صحة الحيوان - معمل الزقازيق الفرعى }
\end{aligned}
$$

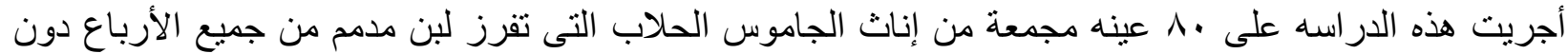

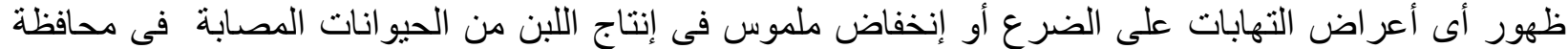

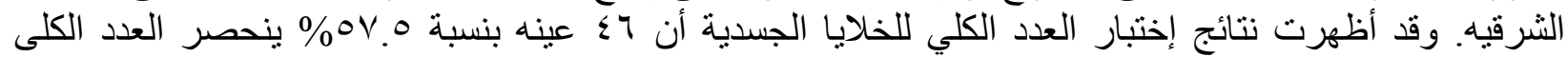

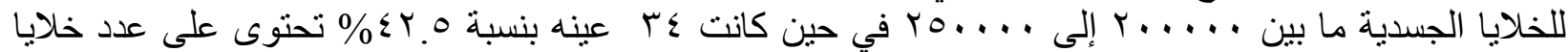
جسدية أقل من . . . . . . . أظهر إختبار الكاليفورنيا أنه سالب لجميع العينات فيما عدا 10 عينة فقط كانت إيجابيه له

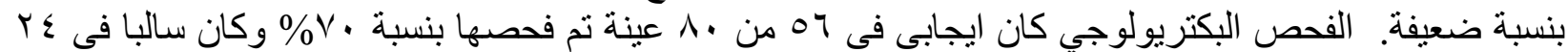

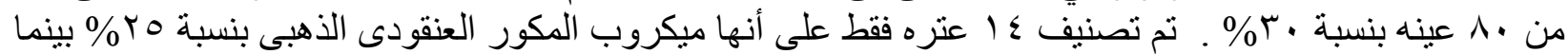

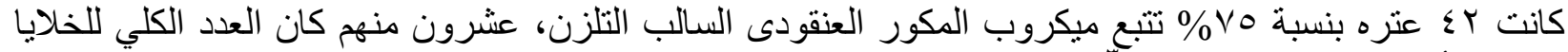

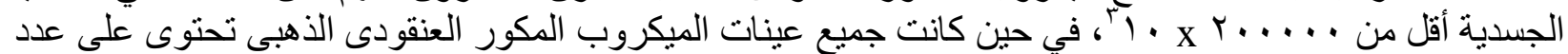

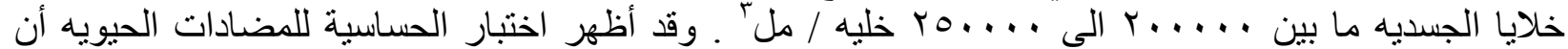

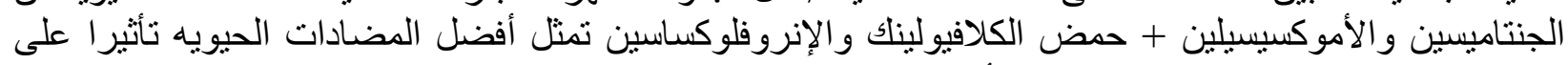
المعزولات سواء المكور العنقودى الذهبى أو المكور العنقودى سالب التلزن ـ عولجت المجموعات او باوبن (إيجابية

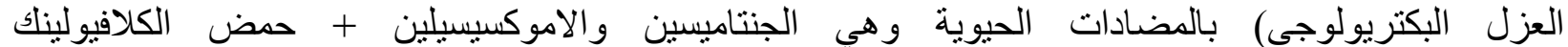

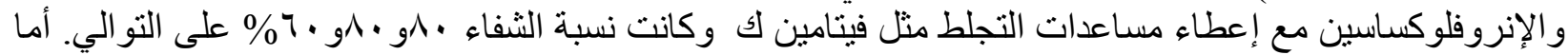

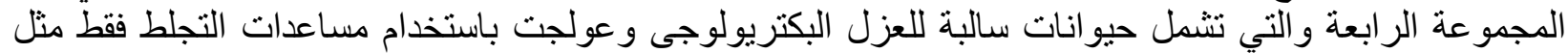

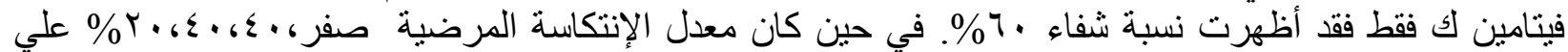
التوالي وقد اظهرت القياسات الهيماتولوجية و البيوكيميائية عدم وجود إختلاف معنوي بين الحالات المصابة والسليمة.

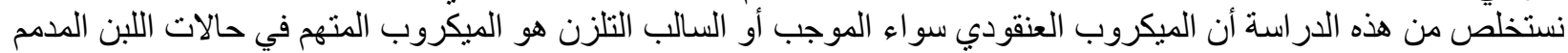

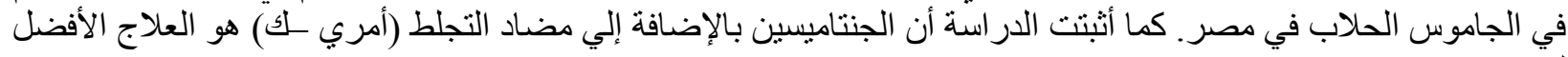

